\title{
Diagnosing marine turbine engines through energy characteristics of their flow sections
}

\begin{abstract}
The aim of the performed research was to develop of a diagnostic method of the flow section of a marine turbine combustion engine based on the level of delamination of its energy characteristics. The here adopted diagnostic model provides for a formulation of the evaluation of the technical conditions based on the measurements of the parameters of the thermodynamic medium in the characteristic control cross-sections of the flow section of the engine during a steady engine operation at nominal load. Based on the energy balancing of the individual impeller sets calculations were performed of their parameters in the form of a distribution of the stream of enthalpy along the flow section. This constituted the basis for the diagnostic conclusions on the overall technical condition of the engine at the same time enabling the identification of the spots of greatest energy losses.
\end{abstract}

Key words: marine turbine combustion engines, energy characteristics of the flow section, diagnostic model

\section{Diagnozowanie okrętowego turbinowego silnika spalinowego na podstawie charakterystyki energetycznej jego części przepływowej}

\begin{abstract}
Istota przeprowadzonych badań było opracowanie metody diagnozowania części przepływowej okrętowego turbinowego silnika spalinowego na podstawie stopnia rozwarstwienia jej charakterystyki energetycznej. Przyjęty w artykule model diagnozowania przewiduje sformułowanie oceny stanu technicznego na podstawie pomiaru parametrów stanu czynnika termodynamicznego w charakterystycznych przekrojach kontrolnych części przeptywowej podczas ustalonej pracy silnika na obciążeniu nominalnym. Na podstawie bilansowania energetycznego poszczególnych zespołów wirnikowych przeprowadza się obliczenia ich parametrów podstawowych przedstawianych w postaci rozkładu strumienia entalpii na dtugości części przepływowej. Stanowi on podstawę wnioskowania diagnostycznego o ogólnym stanie technicznym silnika, umożliwiając jednocześnie lokalizację miejsc powstawania największych strat energetycznych.

Słowa kluczowe: okrętowe turbinowe silniki spalinowe, charakterystyka energetyczna części przepływowej, model diagnozowania
\end{abstract}

\section{Introduction}

By the term flow section of the marine turbine engine we understand the system of its air and exhaust flow channels limited on one side by the deduster gills and the exhaust gas diffuser channel (water cooled) on the other - Fig. 1. The flow section of the engine is characterized by a throughput depending on its dimensions, flow velocity of the working medium, technical conditions of the intervane channels and the connecting channels, the temperature of the flowing working medium etc. This can be described graphically in the form of grid characteristics as a relation of the compression and the mass flow of the working medium $\pi^{*}=\mathrm{f}(\dot{m})$ as shown in Fig. 2. When analyzing the resistance curves of the flow section we can observe that in each case along the growth of the mass flow the flow resistance increases continuously.

During operation the resistance characteristics of the flow section of the turbine engine changes on a continual basis depending on many operating factors:

- contamination or deterioration (wear) of the surface of the flow channels,

- increased temperature of the exhaust gases upstream the turbine $\mathrm{T}_{3}^{*}$,

- changes in the radial play of the engine impellers,

- changes of the angle in the variable geometry compressors and turbines,

\section{Wprowadzenie}

Pod pojęciem części przepływowej okrętowego turbinowego silnika spalinowego należy rozumieć zespół jego powietrznych i spalinowych kanałów przepływowych, ograniczonych z jednej strony płaszczyzną żaluzji wlotu odpylacza powietrza, z drugiej - płaszczyzną w przekroju wylotowym (często chłodzonym wodą), dyfuzorowego kanału spalin wylotowych - rys. 1. Część przepływową silnika charakteryzuje określona zdolność przepustowa uzależniona od jej wymiarów geometrycznych, prędkości przepływu czynnika roboczego, stanu technicznego kanałów międzyłopatkowych i połączeniowych, temperatury przepływającego czynnika itd. Można to zobrazować graficznie w postaci tzw. charakterystyki sieci, jako zależności sprężu od masowego natężenia przepływu czynnika roboczego $\pi^{*}=\mathrm{f}(\dot{\mathrm{m}})$, przedstawionej na rys. 2. Analizując pęk krzywych oporowych części przepływowej, można stwierdzić, że w każdym przypadku wraz ze wzrostem masowego natężenia przepływu opór przepływu nieustannie wzrasta.

W procesie użytkowania charakterystyka oporowa części przepływowej silnika turbinowego zmienia się $\mathrm{w}$ sposób ciągły, w zależności od wpływu wielu czynników eksploatacyjnych:

- zanieczyszczenia lub zużycia powierzchni kanałów przepływowych, 
- actuation of the devices controlling the wastegate system in the flow section.

\section{Energy analysis of a tri-shaft engine}

In order to perform a detailed analysis of the technical conditions of the flow section of the engine in use we need to divide it into characteristic cross-sections and for such impeller sets we need to provide energy balancing $[4,7$, 8]. The obtained thermodynamic relations containing the engine basic gas-dynamic parameters, the relations between the thermodynamic parameters and the structure parameters, the feed, the control and the distortion vectors allow formulating a diagnosis on the current technical conditions of the engine and enable the location of the spots in the flow section of the engine where energy losses occur. Because the flow section of the engine exhaust generator is the most vulnerable engine subcomponent, the technical conditions of its individual elements need to be evaluated with utmost accuracy. Hence, most of the works in the field of diagnostics of turbine engines is devoted to the analysis of phenomena occurring in the flow section of the engine $[2,3,5,6]$. Figure 3 presents schematics of a tri-shaft reversing engine with the control cross-sections of the flow section marked.

From the energy balance of the separate reversing turbine of the tri-shaft engine it results that under steady states the sum of the streams of enthalpy of exhaust buildup inflowing from the exhaust generator and returning to the cooling air circulation (elements of the reversing mechanism) is converted into effective power transferred to the vessel's driveline less the energy loss in the form of enthalpy of the exhaust buildup.

This relation can be expressed in the following form:

$$
\dot{\mathrm{H}}_{42}^{*}+\dot{\mathrm{H}}_{\mathrm{AT} 3}^{*}=\frac{\mathrm{P}_{\mathrm{e}}}{\eta_{\mathrm{mTN}}}+\dot{\mathrm{H}}_{43}^{*}
$$

where: $\dot{\mathrm{H}}_{42}^{*}$ - the stream of enthalpy of the exhaust gas buildup at the exhaust generator, $\dot{\mathrm{H}}_{43}^{*}$-the stream of enthalpy of the exhaust gas buildup at the engine outlet, $\dot{\mathrm{H}}_{\mathrm{AT} 3}^{*}$ - the stream of enthalpy of the air buildup returning to the circulation from behind low-pressure compressor cooling the return mechanism actuators of the drive turbine TN, $\mathrm{P}_{\mathrm{e}}-$ effective power of the engine measured on the turbine shaft, $\eta_{\mathrm{mTN}}-$ mechanical efficiency of the drive turbine impeller.

A characteristic feature of modern marine engines is their complexity of the internal system of air cooling the flow elements in the turbine section (hot) of the engine. For example, for a modern tri-shaft engine by General Electric (LM1600) almost 24\% of the air stream mass pushed through the compressors is fed to the turbine part omitting the combustor $[1,9]$.

After converting formula (1) we obtain a dependence of the engine effective power:

$$
\mathrm{P}_{\mathrm{e}}=\left(\dot{\mathrm{H}}_{42}^{*}-\dot{\mathrm{H}}_{43}^{*}+\dot{\mathrm{H}}_{\mathrm{AT} 3}^{*}\right) \eta_{\mathrm{mTN}}
$$

- podwyższenia temperatury spalin przed turbiną $\mathrm{T}_{3}^{*}$, - zmiany wartości luzów promieniowych wirników silnika,

- zmiany kąta nastawnych kierownic sprężarek i turbin, - przystąpienia do pracy urządzeń sterujących upustem powietrza z części przepływowej.

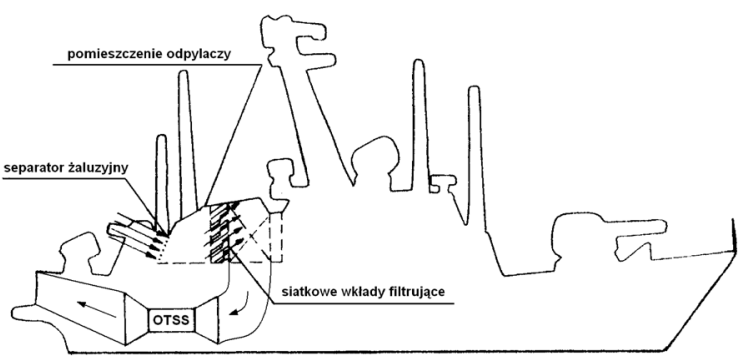

Fig. 1. Schematics of the positions of the intake air channels and exhaust gas ducts in the flow section of the Zorya UGT6000 engine in the hull of a corvette 'Tarantula'

Rys. 1. Schemat rozmieszczenia kanałów powietrza dolotowego i spalin wylotowych czesści przeptywowej silnika Zorya UGT6000 w kadtubie korwety , Tarantula”

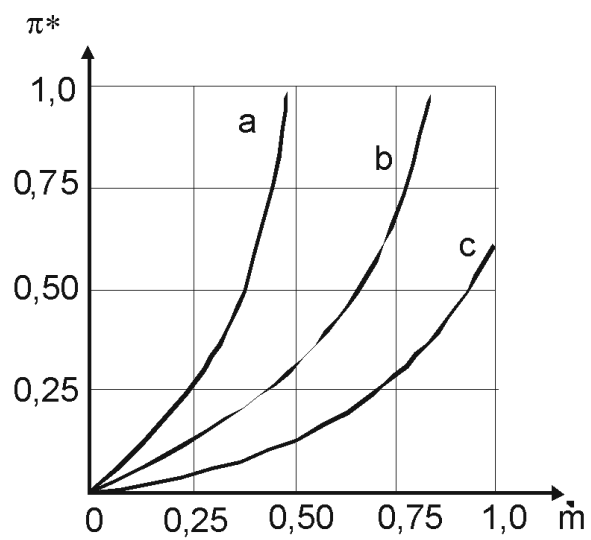

Fig. 2. Resistance characteristics of the flow section of a turbine combustion engine: a) increase in the flow resistance, b) calculation conditions, c) decrease in the flow resistance

Rys. 2. Charakterystyka oporowa (sieci) części przeptywowej turbinowego silnika spalinowego: a) wzrost oporów przepływu, b) warunki obliczeniowe, c) zmniejszenie oporów przepływu

\section{Analiza energetyczna silnika trzywałowego}

Aby dokonać szczegółowej oceny stanu technicznego części przepływowej silnika w eksploatacji, należy ją umownie podzielić $\mathrm{w}$ charakterystycznych przekrojach, a utworzone w ten sposób zespoły wirnikowe zbilansować energetycznie $[4,7,8]$. Otrzymane zależności termodynamiczne, ujmujące podstawowe parametry gazodynamiczne silnika, znajomość relacji pomiędzy parametrami termodynamicznymi a parametrami struktury konstrukcyjnej, znajomość wektorów zasilania, sterowania i zakłóceń pozwalają na postawienie diagnozy jego aktualnego stanu technicznego, jak również umożliwiają określenie miejsca części przepływowej, w której powstają straty energii silnika. Ponieważ część przepływowa wytwornicy spalin silnika jest najbardziej newralgicznym podzespołem silnika, stan 
Hence, the engine power is most of all influenced by:

- the drop of the stream of enthalpy of the exhaust gas buildup in the process of actual decompression in the drive turbine,

- the stream of enthalpy of the cooling air returning to the circulation,

- the mechanical efficiency of the drive turbine impeller.

If we want to correlate the gas-dynamic parameters of the whole engine in terms of their influence on the power output, we need to perform energy balancing for the impeller sets of the exhaust gas generator and the combustor.

From the energy balance of the low-pressure impeller system it results that:

$$
\mathrm{P}_{\mathrm{eSNC}}=\mathrm{P}_{\mathrm{eTNC}} \cdot \eta_{\mathrm{mNC}}
$$

or

$$
\dot{\mathrm{H}}_{21}^{*}-\dot{\mathrm{H}}_{11}^{*}=\left(\dot{\mathrm{H}}_{32}^{*}-\dot{\mathrm{H}}_{42}^{*}\right) \eta_{\mathrm{mNC}}
$$

hence

$$
\dot{\mathrm{H}}_{42}^{*}=\dot{\mathrm{H}}_{32}^{*}-\frac{\left(\dot{\mathrm{H}}_{21}^{*}-\dot{\mathrm{H}}_{11}^{*}\right)}{\eta_{\mathrm{mNC}}}
$$

where: $\mathrm{P}_{\mathrm{eSNC}}, \mathrm{P}_{\text {eTNC }}$ - effective power of: low-pressure compressor and turbine, $\dot{H}_{32}^{*}$ - stream of enthalpy of the exhaust gas buildup at the outlet from the variable geometry vanes of the low-pressure compressor TNC, $\dot{\mathrm{H}}_{11}^{*}, \dot{\mathrm{H}}_{21}^{*}$ - stream of enthalpy of the air buildup: in the intake cross-section and at the outlet from the low-pressure compressor SNC, $\eta_{\mathrm{mNC}}-$ mechanical efficiency of the low pressure impeller system.

Substituting dependence (5) to engine effective power formula (2) we obtain:

$$
\mathrm{P}_{\mathrm{e}}=\left[\dot{\mathrm{H}}_{32}^{*}-\dot{\mathrm{H}}_{43}^{*}-\frac{\left(\dot{\mathrm{H}}_{21}^{*}-\dot{\mathrm{H}}_{11}^{*}\right)}{\eta_{\mathrm{mNC}}}+\dot{\mathrm{H}}_{\mathrm{AT} 3}^{*}\right] \cdot \eta_{\mathrm{mTN}}
$$

From the energy balancing for the low-pressure turbine variable geometry vanes it results that:

$$
\dot{\mathrm{H}}_{32}^{*}=\dot{\mathrm{H}}_{41}^{*}+\dot{\mathrm{H}}_{\mathrm{AT} 2}^{*}
$$

where: $\dot{\mathrm{H}}_{41}^{*}$ - the stream of enthalpy of the exhaust gas buildup at the outlet from the high-pressure turbine impeller, $\dot{\mathrm{H}}_{\mathrm{AT} 2}^{*}$ - stream of enthalpy of the returning air buildup from techniczny jej poszczególnych elementów należy oceniać szczególnie wnikliwie. Stąd większość publikowanych prac z dziedziny diagnostyki turbinowych silników spalinowych poświęcona jest właśnie analizie zjawisk zachodzących w części przepływowej silnika [2, 3, 5, 6]. Na rysunku 3 przedstawiono schemat ideowy silnika trzywałowego o konstrukcji nawrotnej z zaznaczonymi przekrojami kontrolnymi części przepływowej.

$\mathrm{Z}$ bilansu energetycznego oddzielnej, nawrotnej turbiny napędowej silnika trzywałowego wynika, że w stanach pracy ustalonej suma strumieni entalpii spiętrzenia spalin napływających z wytwornicy i powracającego do obiegu powietrza chłodzącego (elementy mechanizmu nawrotu) zamieniona zostaje na moc efektywną przekazywaną na linię napędową okrętu, pomniejszoną o stratę energii w postaci strumienia entalpii spiętrzenia spalin wylotowych.

Zależność tę można zapisać w postaci wzoru (1), gdzie: $\dot{\mathrm{H}}_{42}^{*}$ - strumień entalpii spiętrzenia spalin na wyjściu z wytwornicy spalin, $\dot{\mathrm{H}}_{43}^{*}$ - strumień entalpii spiętrzenia spalin na wyjściu z silnika, $\dot{\mathrm{H}}_{\mathrm{AT} 3}^{*}$ - strumień entalpii spiętrzenia powracającego do obiegu powietrza zza SNC, chłodzącego wykonawcze elementy mechanizmu nawrotu $\mathrm{TN}, \mathrm{P}_{\mathrm{e}}-$ moc efektywna silnika na wale turbiny napędowej, $\eta_{\mathrm{mTN}}-$ sprawność mechaniczna wirnika turbiny napędowej.

Cechą charakterystyczną współcześnie produkowanych silników okrętowych jest znaczne rozbudowanie instalacji wewnętrznej powietrza chłodzącego elementy przepływowe w części turbinowej (gorącej) silnika. Przykładowo, dla najnowszego silnika trzywałowego firmy General Electric typu LM1600 prawie 24\% strumienia masy powietrza przetłaczanego w sprężarkach doprowadzane jest do części turbinowej z pominięciem komory spalania $[1,9]$. 
behind the high-pressure compressor (the air cooling the variable geometry vanes of the low pressure turbine).

Substituting dependence (7) to engine effective power formula (6) we obtain:

$$
\mathrm{P}_{\mathrm{e}}=\left[\dot{\mathrm{H}}_{41}^{*}-\dot{\mathrm{H}}_{43}^{*}-\frac{\left(\dot{\mathrm{H}}_{21}^{*}-\dot{\mathrm{H}}_{11}^{*}\right)}{\eta_{\mathrm{mNC}}}+\dot{\mathrm{H}}_{\mathrm{AT} 2}^{*}+\dot{\mathrm{H}}_{\mathrm{AT} 3}^{*}\right] \cdot \eta_{\mathrm{mTN}}
$$

From the energy balance of the high-pressure impeller system it results that:

$$
\mathrm{P}_{\mathrm{eSWC}}=\mathrm{P}_{\mathrm{eTWC}} \cdot \eta_{\mathrm{mWC}}
$$

or

$$
\dot{\mathrm{H}}_{22}^{*}-\dot{\mathrm{H}}_{12}^{*}=\left(\dot{\mathrm{H}}_{31}^{*}+\dot{\mathrm{H}}_{\mathrm{AT} 1}^{*}-\dot{\mathrm{H}}_{41}^{*}\right) \eta_{\mathrm{mWC}}
$$

hence

$$
\dot{\mathrm{H}}_{41}^{*}=\dot{\mathrm{H}}_{31}^{*}+\dot{\mathrm{H}}_{\mathrm{AT} 1}^{*}-\frac{\left(\dot{\mathrm{H}}_{22}^{*}-\dot{\mathrm{H}}_{12}^{*}\right)}{\eta_{\mathrm{mwC}}}
$$

where: $\mathrm{P}_{\text {eSWC }}, \mathrm{P}_{\text {eTWC }}$ - effective power of: high-pressure compressor and turbine, $\dot{\mathrm{H}}_{31}^{*}$ - stream of enthalpy of the exhaust gas buildup at the outlet from the variable geometry vanes in the high-pressure turbine, $\dot{\mathrm{H}}_{\mathrm{AT} 1}^{*}-$ stream of enthalpy of the returning air buildup from behind the high-pressure compressor (the air cooling the impeller vanes of the high pressure turbine), $\dot{\mathrm{H}}_{12}^{*}, \dot{\mathrm{H}}_{22}^{*}$ - stream of enthalpy of the air buildup: in the intake and outlet cross-section of the highpressure compressor, $\eta_{\mathrm{mWC}}-$ mechanical efficiency of the high-pressure impeller system.

Substituting dependence (11) to engine effective power formula (8) we obtain:

$$
\mathrm{P}_{\mathrm{e}}=\left[\begin{array}{l}
\dot{\mathrm{H}}_{31}^{*}-\dot{\mathrm{H}}_{43}^{*}-\frac{\left(\dot{\mathrm{H}}_{22}^{*}-\dot{\mathrm{H}}_{12}^{*}\right)}{\eta_{\mathrm{mWC}}}+ \\
-\frac{\left(\dot{\mathrm{H}}_{21}^{*}-\dot{\mathrm{H}}_{11}^{*}\right)}{\eta_{\mathrm{mNC}}}+\dot{\mathrm{H}}_{\mathrm{AT} 1}^{*}+ \\
+\dot{\mathrm{H}}_{\mathrm{AT} 2}^{*}+\dot{\mathrm{H}}_{\mathrm{AT} 3}^{*}
\end{array}\right] \cdot \eta_{\mathrm{mTN}}
$$

From the energy balancing for the high-pressure turbine variable geometry channel it results that:

$$
\dot{\mathrm{H}}_{31}^{*}=\dot{\mathrm{H}}_{3}^{*}+\dot{\mathrm{H}}_{\mathrm{A} 21}^{*}
$$

where: $\dot{\mathrm{H}}_{3}^{*}$ - stream of enthalpy of the exhaust gas buildup at the outlet of the combustor, $\dot{\mathrm{H}}_{\mathrm{A} 21}^{*}$ - stream of enthalpy of the returning air buildup from behind the high-pressure compressor (the air cooling the variable geometry vanes of the high pressure turbine).

Substituting dependence (13) to engine effective power formula (12) we obtain:
Po przekształceniu wzoru (1) otrzymuje się zależność na moc efektywną silnika - wzór (2).

Tak więc na moc silnika ma wpływ przede wszystkim: - spadek strumienia entalpii spiętrzenia spalin, w procesie rzeczywistego procesu rozprężania w turbinie napędowej,

- strumień entalpii spiętrzenia powietrza chłodzącego, powracającego do obiegu,

- sprawność mechaniczna wirnika turbiny napędowej.

Chcąc powiązać ze sobą parametry gazodynamiczne całego silnika, w sensie ich wpływu na moc wyjściową, należy zbilansować energetycznie zespoły wirnikowe wytwornicy spalin oraz komorę spalania.

$Z$ bilansu energetycznego zespołu wirnikowego niskiego ciśnienia wynika wzór (3) lub (4), stąd (5), gdzie: $\mathrm{P}_{\text {eSNC }}$, $\mathrm{P}_{\text {eTNC }}-$ moc efektywna odpowiednio: sprężarki i turbiny niskiego ciśnienia, $\dot{H}_{32}^{*}$ - strumień entalpii spiętrzenia spalin na wyjściu z kierownicy TNC, $\dot{\mathrm{H}}_{11}^{*}, \dot{\mathrm{H}}_{21}^{*}$ - strumień entalpii spiętrzenia powietrza, odpowiednio: $\mathrm{w}$ przekroju wejściowym silnika i na wyjściu z SNC, $\eta_{\mathrm{mNC}}$ - sprawność mechaniczna zespołu wirnikowego niskiego ciśnienia.

Podstawiając zależność (5) do wyrażenia na moc efektywną silnika (2), otrzymuje się (6).

$\mathrm{Z}$ bilansu energetycznego dla kierownicy turbiny niskiego ciśnienia wynika wzór (7), gdzie: $\dot{\mathrm{H}}_{41}^{*}$ - strumień entalpii spiętrzenia spalin na wyjściu z wirnika TWC, $\dot{\mathrm{H}}_{\mathrm{AT} 2}^{*}$ - strumień entalpii spiętrzenia powracającego do obiegu powietrza zza SWC, chłodzącego łopatki kierownicze TNC.

Podstawiając zależność (7) do wyrażenia na moc efektywną silnika (6), otrzymuje się wzór (8).

Z bilansu energetycznego zespołu wirnikowego wysokiego ciśnienia wynika - wzór (9) lub (10), stąd (11), gdzie: $\mathrm{P}_{\text {eSWC }}, \mathrm{P}_{\text {eTWC }}-$ moc efektywna odpowiednio: sprężarki i turbiny wysokiego ciśnienia, $\dot{\mathrm{H}}_{31}^{*}$ - strumień entalpii spiętrzenia spalin na wyjściu z kierownicy TWC, $\dot{H}_{\mathrm{AT} 1}^{*}$ - strumień entalpii spiętrzenia powracającego do obiegu powietrza zza SWC, chłodzącego łopatki wirnikowe TWC, $\dot{\mathrm{H}}_{12}^{*}, \dot{\mathrm{H}}_{22}^{*}$ - strumień entalpii spiętrzenia powietrza, odpowiednio: $\mathrm{w}$ przekroju wejściowym i wyjściowym SWC, $\eta_{\mathrm{mWC}}$ - sprawność mechaniczna zespołu wirnikowego wysokiego ciśnienia.

Podstawiając zależność (11) do wyrażenia na moc efektywną silnika (8), otrzymuje się (12).

$Z$ bilansu energetycznego dla kierownicy turbiny wysokiego ciśnienia wynika (13), gdzie: $\dot{\mathrm{H}}_{3}^{*}$ - strumień entalpii spiętrzenia spalin na wyjściu z komory spalania KS, $\dot{\mathrm{H}}_{\mathrm{A} 21}^{*}$ - strumień entalpii spiętrzenia powracającego do obiegu powietrza zza SWC, chłodzącego łopatki kierownicze TWC.

Podstawiając zależność (13) do wyrażenia na moc efektywną silnika (12), otrzymuje się (14) lub (15), gdzie: $\Delta \dot{\mathrm{H}}_{\mathrm{TWC}(\mathrm{iz})}^{*}, \Delta \dot{\mathrm{H}}_{\mathrm{TNC}(\mathrm{iz})}^{*}, \Delta \dot{\mathrm{H}}_{\mathrm{TN}(\mathrm{iz})}^{*}-$ izentropowe spadki entalpii spiętrzenia strumienia spalin odpowiednio w: TWC, TNC i TN, $\eta_{\mathrm{eTWC}}^{*}, \eta_{\mathrm{eTNC}}^{*}, \eta_{\mathrm{eTN}}^{*}, \eta_{\mathrm{eSWC}}^{*}, \eta_{\mathrm{eSNC}}^{*}-$ sprawności procesów rozprężania i sprężania czynnika roboczego $\mathrm{w}$ sprężarkach i turbinach silnika, wyrażone w parametrach 


$$
\mathrm{P}_{\mathrm{e}}=\left[\begin{array}{c}
\dot{\mathrm{H}}_{3}^{*}-\dot{\mathrm{H}}_{43}^{*}-\frac{\left(\dot{\mathrm{H}}_{22}^{*}-\dot{\mathrm{H}}_{12}^{*}\right)}{\eta_{\mathrm{mWC}}}- \\
+\frac{\left(\dot{\mathrm{H}}_{21}^{*}-\dot{\mathrm{H}}_{11}^{*}\right)_{+}}{\eta_{\mathrm{mNC}}}+\dot{\mathrm{H}}_{\mathrm{A} 21}^{*}+ \\
+\dot{\mathrm{H}}_{\mathrm{AT} 1}^{*}+\dot{\mathrm{H}}_{\mathrm{AT} 2}^{*}+\dot{\mathrm{H}}_{\mathrm{AT} 3}^{*}
\end{array}\right] \cdot \eta_{\mathrm{mTN}}
$$

or

$$
\mathrm{P}_{\mathrm{e}}=\left[\begin{array}{c}
\Delta \dot{\mathrm{H}}_{\mathrm{TWC}(\mathrm{iz})}^{*} \cdot \eta_{\mathrm{eTWC}}^{*}+\Delta \dot{\mathrm{H}}_{\mathrm{TNC}(\mathrm{iz})}^{*} \cdot \eta_{\mathrm{eTNC}}^{*}+ \\
+\Delta \dot{\mathrm{H}}_{\mathrm{TN}(\mathrm{iz})}^{*} \cdot \eta_{\mathrm{eTN}}^{*}-\frac{\dot{\mathrm{m}}_{\mathrm{powSWC}} \cdot 1_{\mathrm{SWC}(\mathrm{iz})}^{*}}{\eta_{\mathrm{eSWC}}^{*} \cdot \eta_{\mathrm{mWC}}}+ \\
-\frac{\dot{\mathrm{m}}_{\mathrm{powSNC}} \cdot 1_{\mathrm{SNC}(\mathrm{iz})}^{*}}{\eta_{\mathrm{eSNC}}^{*} \cdot \eta_{\mathrm{mNC}}}+\dot{\mathrm{H}}_{\mathrm{A} 21}^{*}+\dot{\mathrm{H}}_{\mathrm{AT} 1}^{*}+ \\
+\dot{\mathrm{H}}_{\mathrm{AT} 2}^{*}+\dot{\mathrm{H}}_{\mathrm{AT} 3}^{*}
\end{array}\right] \cdot \eta_{\mathrm{mTN}}(
$$

where: $\Delta \dot{\mathrm{H}}_{\mathrm{TWC}(\mathrm{iz})}^{*}, \Delta \dot{\mathrm{H}}_{\mathrm{TNC}(\mathrm{iz})}^{*}, \Delta \dot{\mathrm{H}}_{\mathrm{TN}(\mathrm{iz})}^{*}-$ isentropic drops of the enthalpy of the stream of exhaust buildup in: highpressure turbine, low-pressure turbine and drive turbine, $\eta_{\mathrm{eTWC}}^{*}, \eta_{\mathrm{eTNC}}^{*}, \eta_{\mathrm{eTN}}^{*}, \eta_{\mathrm{eSWC}}^{*}, \eta_{\mathrm{eSNC}}^{*}-$ the efficiencies of the processes of compressing and decompressing of the working medium in the engine compressors and turbines expressed in the buildup parameters, $1_{\mathrm{SWC}(\mathrm{iz})}^{*} 1_{\mathrm{SNC}(\mathrm{iz})}^{*}$ - proper work of the isentropic process of compression in: high-pressure compressor and low-pressure compressor, $\dot{\mathrm{m}}_{\text {powswC }}, \dot{\mathrm{m}}_{\text {powSNC }}$ - stream of mass of the compressed air in: high-pressure compressor and low-pressure compressor.

After a conversion of expression (15) and taking into account the dependencies connecting its individual basic elements, the formula for the engine power output has the following form:

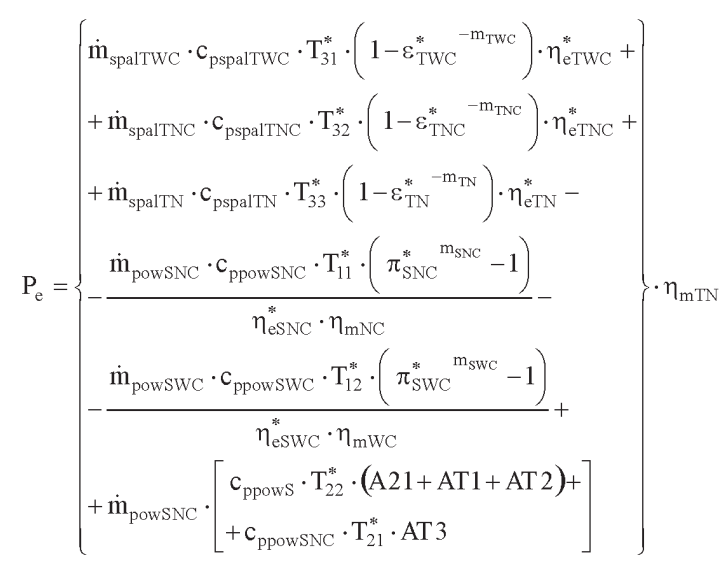

where: $c_{\text {pspalTwC }}, c_{\text {pspalTNC }}, c_{\text {pspalTN }}, c_{\text {ppowSNC }}, c_{\text {ppowSwC }}, c_{\text {ppows }}-$ mean specific heat in the range of isentropic processes of compression and decompression of the working medium in: high-pressure turbine, low-pressure turbine, drive turbine, low-pressure compressor, high-pressure compressor and both compressors, $\dot{\mathrm{m}}_{\text {spalTWC }}, \dot{\mathrm{m}}_{\text {spalTNC }}, \dot{\mathrm{m}}_{\text {spalTN }}$ spiętrzenia, $1_{\text {SWC(iz) }}^{*} 1_{\text {SNC(iz) }}^{*}$-praca właściwa izentropowego procesu sprężania odpowiednio w: SWC i SNC, $\dot{\mathrm{m}}_{\text {powSWC }}, \dot{\mathrm{m}}_{\text {powSNC }}$ - strumień masy powietrza sprężanego odpowiednio w: SWC i SNC.

Po przekształceniu wyrażenia (15) i uwzględnieniu zależności wiążących jego poszczególne człony podstawowe, wzór na moc obliczeniową silnika przyjął postać (16), gdzie: $\mathrm{c}_{\text {pspalTWC }}, \mathrm{c}_{\text {pspalTNC }}, \mathrm{c}_{\text {pspalTN }}, \mathrm{c}_{\text {ppowSNC}}, \mathrm{c}_{\text {ppowSWC }}, \mathrm{c}_{\text {ppows }}-$ średnie ciepła właściwe spalin rzeczywistych i powietrza w zakresie izentropowych procesów rozprężania i sprężania czynnika roboczego odpowiednio w: TWC, TNC, TN, SNC, SWC i obu sprężarkach, $\dot{\mathrm{m}}_{\text {spalTWC }}, \dot{\mathrm{m}}_{\text {spalTNC }}, \dot{\mathrm{m}}_{\text {spalTN }}$ - strumień masy spalin rozprężanych odpowiednio w: TWC, TNC i $\mathrm{TN}, \mathrm{m}_{\mathrm{TWC}}, \mathrm{m}_{\mathrm{TNC}}, \mathrm{m}_{\mathrm{TN}}, \mathrm{m}_{\mathrm{SNC}}, \mathrm{m}_{\mathrm{SWC}}$ - umowny wykładnik potęgowy równy $(\chi-1) \chi \chi$ dla zakresów temperaturowych poszczególnych zespołów wirnikowych, $\varepsilon_{\mathrm{TWC}}^{*}, \varepsilon_{\mathrm{TNC}}^{*}, \varepsilon_{\mathrm{TN}}^{*}-$ stosunek ciśnień w turbinie odpowiednio: TWC, TNC i TN, $\pi_{\mathrm{SWC}}^{*}, \pi_{\mathrm{SNC}}^{*}$ - spręż sprężarki odpowiednio: SWC i SNC, $\mathrm{T}_{31}^{*}, \mathrm{~T}_{32}^{*}, \mathrm{~T}_{33}^{*}, \mathrm{~T}_{11}^{*}, \mathrm{~T}_{12}^{*}, \mathrm{~T}_{21}^{*}, \mathrm{~T}_{22}^{*}$ - temperatury bezwzględne spiętrzonego strumienia czynnika roboczego w przekrojach kontrolnych silnika, A21, AT1, AT2, AT3 - względne udziały masowe powracającego do obiegu strumienia powietrza chłodzącego łopatki turbin i mechanizm nawrotu oddzielnej turbiny napędowej.

Z formuły (16) opisującej zależność mocy trzywałowego silnika turbinowego z oddzielną turbiną napędową można wyciągnąc następujące, ogólne wnioski, które w sposób logiczny porządkują zagadnienie diagnozowania części przepływowej: moc efektywna uzyskiwana na wale wyjściowym silnika jest funkcją:

- strumienia masy czynnika roboczego, zdeterminowanego przede wszystkim doskonałością kształtu i stanem powierzchni kanałów przepływowych, a także stanem kanałów transportujących powietrze chłodzące do części turbinowej z pominięciem komory spalania,

- średniego ciepła właściwego powietrza i spalin, a wiec składu spalin i rozkładu temperatury wzdłuż części przepływowej silnika,

- efektywnych sprawności maszyn wirnikowych, które odzwierciedlają doskonałość procesów przekształcania energii w sprężarkach i turbinach.

\section{Charakterystyka energetyczna części przeplywowej}

W procesie eksploatacji silnika okrętowego przeprowadza się systematyczną ocenę stanu technicznego według analizy trendów zmian charakterystyki energetycznej jego części przepływowej - rys. 4 [7, 8]. Stanowi ona rozkład strumienia entalpii czynnika roboczego wzdłuż kanału przepływowego $\dot{\mathrm{H}}_{\mathrm{X}-\mathrm{X}}^{*}=\mathrm{f}(\mathrm{L})$, który jest sporządzony na podstawie bilansowania energetycznego poszczególnych maszyn przepływowych dla ustalonego zakresu obciążenia, najczęściej dla $1.0 \mathrm{P}_{\text {nom }}$. Określany w wyniku badań eksperymentalnych tzw. stopień rozwarstwienia charakterystyki energetycznej w poszczególnych przekrojach kontrolnych silnika $\mathrm{x}-\mathrm{x}$ wyznacza miarę 
- stream of mass of the decompressed exhaust in: highpressure turbine, low-pressure turbine and drive turbine, $\mathrm{m}_{\mathrm{TWC}}, \mathrm{m}_{\mathrm{TNC}}, \mathrm{m}_{\mathrm{TN}}, \mathrm{m}_{\mathrm{SNC}}, \mathrm{m}_{\mathrm{SWC}}$ - arbitrary power index equal to $(\chi-1) / \chi$ for temperature ranges of the individual impeller systems, $\varepsilon_{\mathrm{TWC}}^{*}, \varepsilon_{\mathrm{TNC}}^{*}, \varepsilon_{\mathrm{TN}}^{*}$ - ratio of pressures in the turbine: high-pressure turbine, low-pressure turbine and drive turbine, $\pi_{\mathrm{SWC}}^{*}, \pi_{\mathrm{SNC}}^{*}-$ compression of the compressor of: high-pressure compressor and low-pressure compressor, $\mathrm{T}_{31}^{*}, \mathrm{~T}_{32}^{*}, \mathrm{~T}_{33}^{*}, \mathrm{~T}_{11}^{*}, \mathrm{~T}_{12}^{*}, \mathrm{~T}_{21}^{*}, \mathrm{~T}_{22}^{*}$ - absolute temperatures of the built-up working medium in the control cross-sections of the engine, A21, AT1, AT2, AT3 - relative mass shares of the returning air stream that cools the turbine vanes and the returning mechanism of the separate drive turbine.

From formula (16) describing the dependence of the power of the tri-shaft turbine engine with a separate drive turbine we can draw the following general conclusions that logically sort out the issue of diagnosing of the flow section of the engine: the effective power measured on the engine shaft is a function of:

- the stream of mass of the working medium, determined by the perfection of the shape and condition of the flow channel walls as well as the condition of the channels transporting the cooling air to the turbine section omitting the combustor;

- mean specific heat of the air and exhaust gases, hence the composition of the exhaust and temperature distribution along the flow section of the engine;

- effective impeller machine efficiencies that reflect the perfection of the processes of energy conversion in compressors and turbines.

\section{Energy characteristics of the flow section of the engine}

In the process of marine engine operation a regular evaluation of the technical condition is carried out following the analysis of the trends in the changes of the energy characteristics of its flow section - Fig. 4 [7, 8]. It is the distribution of the stream of enthalpy of the working medium along the flow channel $\dot{\mathrm{H}}_{\mathrm{X}-\mathrm{X}}^{*}=\mathrm{f}(\mathrm{L})$ that is made based on the energy balance of the individual flow machines for a set range of loads, most frequently for $1.0 \mathrm{P}_{\text {nom }}$. The level of delamination of the energy characteristics in individual control sections of the engine $\mathrm{x}-\mathrm{x}$ determined in experimental research sets out the measure of the generalized diagnostic parameter calculated from the dependence:

$$
\Delta \dot{\mathrm{H}}_{\mathrm{X}-\mathrm{X}}^{*}=\dot{\mathrm{H}}_{\mathrm{X}-\mathrm{X}(\mathrm{pom})}^{*}-\dot{\mathrm{H}}_{\mathrm{X}-\mathrm{X}(\mathrm{o})}^{*}
$$

Based on the above we can characterize the tested engine in terms of the consequence uogólnionego parametru diagnostycznego obliczanego z zależności (17).

Na tej podstawie można scharakteryzować badany silnik pod wpływem konsekwencji zmian stanu technicznego części przepływowej, wskutek jej zanieczyszczenia lub zużycia, na rozdział dysponowanego spadku entalpii na turbiny silnika oraz moc na wale wyjściowym.

Charakterystyka energetyczna części przepływowej, zaprezentowana na rys. 4, wykonana została na podstawie wyników badań eksperymentalnych seryjnego silnika Zarya typu UGT600, w ramach prób ruchowych okrętu w morzu. Pomiary parametrów gazodynamicznych przeprowadzono w dwóch stanach silnika różnych od siebie: przed i po myciu części przepływowej.

Analiza porównawcza obliczonych rozkładów zmian strumienia entalpii czynnika roboczego dla silnika fabrycznie nowego i tego samego silnika w dwóch rozpatrywanych stanach części przepływowej potwierdziła szczególną wrażliwość wielostopniowych sprężarek osiowych na wzrost chropowatości powierzchni bardzo zanieczyszczonych kanałów międzyłopatkowych. Względne zmiany strumienia entalpii w części sprę-

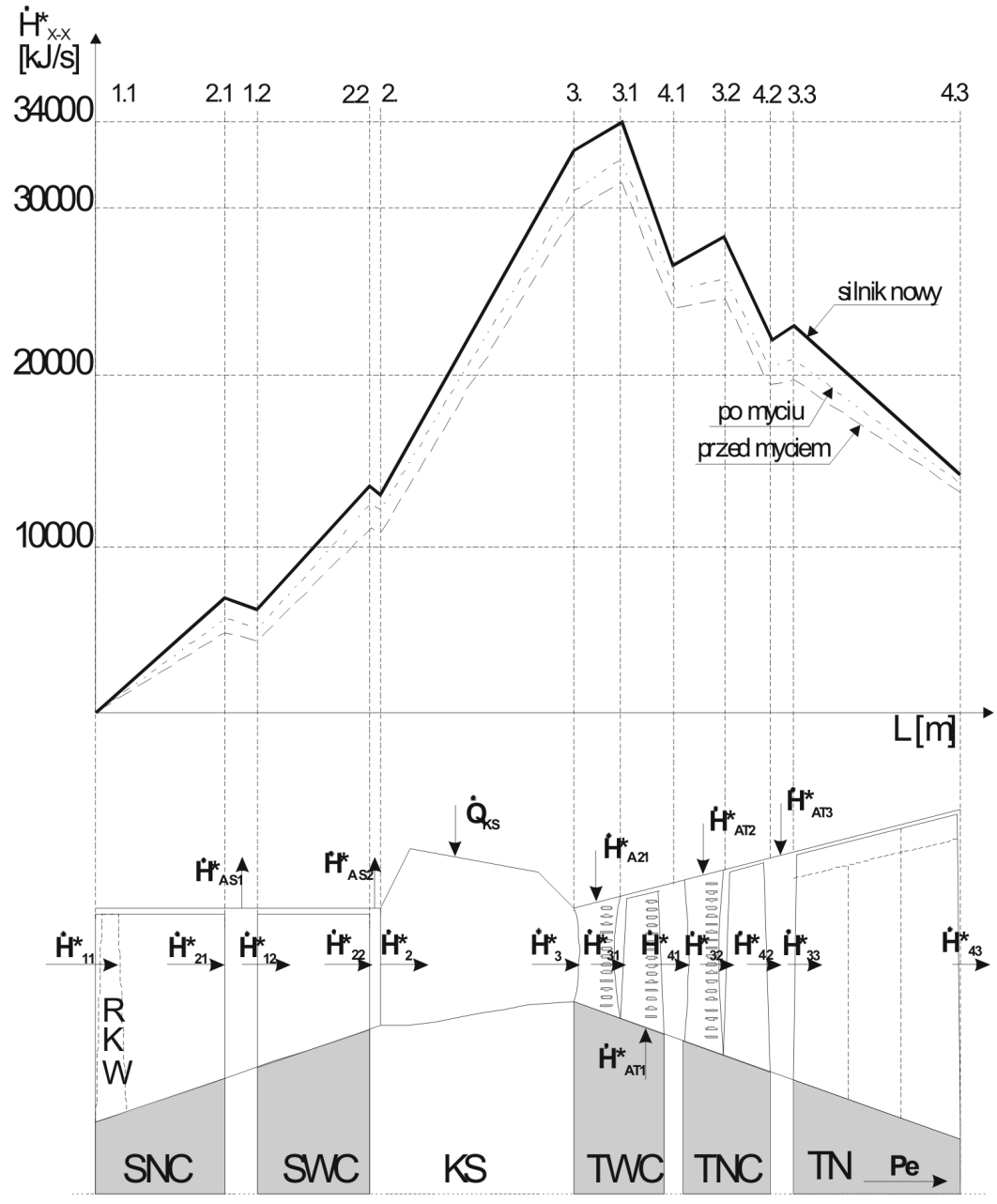

Fig. 4. Schematics of the flow section of the Zorya UGT6000 engine with the distribution of the stream of enthalpy of the working medium in the characteristic control cross-sections

Rys. 4. Schemat ideowy części przepływowej silnika Zorya UGT6000 z rozkładem strumienia entalpii czynnika roboczego $w$ charakterystycznych przekrojach kontrolnych 
of changes of the technical conditions of its flow section as a result of its contamination or wear on the distribution of the decrease of enthalpy in the engine turbines and the influence on the power output measured on the shaft.

The energy characteristics of the flow section presented in Fig. 4 has been performed based on the results of experimental research of a serially manufactured Zarya UGT600 engine during the marine vessel trials at sea. The measurements of the gas-dynamic parameters were performed in two different engine states: before and after cleaning of the flow section of the engine.

The comparative analysis of the calculated distributions of the changes of the stream of enthalpy of the working medium for a brand new engine analyzed in two different states of the flow section has confirmed the sensitivity of the multistage axial compressors to the roughness of the surface of highly contaminated intervane channels. The relative changes in the stream of enthalpy in the compressor section are almost twice as high in comparison to the turbine section.

According to the nature of the distribution of the decrease of enthalpy onto individual engine turbines, in case of deviation from the operating parameters as a result of contamination of the flow section, the greatest decrease in power takes place on the separate drive turbine (power output) and the smallest on the highpressure turbine. The drop of the relative value of power of the high-pressure turbine was $4.47 \%$, low-pressure turbine $-4.88 \%$ and the separate drive turbine $-5.62 \%$. We may expect that at engine part loads these drops will be much greater, definitely deteriorating the engine performance and efficiency.

\section{Conclusions}

The here proposed method of engine diagnostics according to the nature of the changes of the stream of enthalpy of the working medium along the flow section of the engine enables qualitative and quantitative identification of the technical condition of individual machines.

In order to validate the obtained measurement results, perform calculations of the basic energy-related parameters of the engine and obtain information on the quality of the flow section cleaning process endoscopic investigations have been carried out twice. It revealed a fairly good effectiveness of the flow channel cleaning thus confirming the changes in the technical conditions of the vane profiles and their consequence in the form of recorded deformations (delamination) of the energy-related characteristics of the flow section of the engine.

Paper reviewed/Artykut recenzowany

Zbigniew Korczewski, DSc., DEng. - professor in the Faculty of Ocean Engineering and Ship Technology at Gdansk University of Technology. Prof. dr hab. inż. Zbigniew Korczewski-profesor na Wydziale Oceanotechniki i Okrętownictwa Politechniki Gdańskiej.

e-mail: z.korczewski@gmail.com żarkowej są prawie dwukrotnie większe niż w części turbinowej.

Zgodnie z charakterem rozdziału dysponowanego spadku entalpii na poszczególne turbiny silnika, w przypadku odchylenia od obliczeniowych parametrów pracy wskutek zanieczyszczenia części przepływowej, największy spadek mocy następuje na oddzielnej turbinie napędowej (mocy silnika), zaś najmniejszy na turbinie wysokiego ciśnienia. Spadek względnej wartości mocy turbiny wysokiego ciśnienia wynosił $4,47 \%$, turbiny niskiego ciśnienia - 4,88\%, a oddzielnej turbiny napędowej-5,62\%. Można oczekiwać, że na obciążeniach częściowych silnika spadki te będą znacznie większe, pogarszając w zdecydowany sposób osiągi i sprawność silnika.

\section{Podsumowanie}

Zaproponowany w artykule sposób diagnozowania silnika według charakteru zmian rozkładu strumienia entalpii czynnika roboczego wzdłuż kanału przepływowego umożliwia identyfikację stanu technicznego poszczególnych maszyn pod względem ilościowym i jakościowym.

W celu weryfikacji otrzymanych wyników pomiarowych oraz przeprowadzonych obliczeń podstawowych parametrów energetycznych silnika, a także uzyskania informacji o jakości przeprowadzonego mycia części przepływowej przeprowadzono dwukrotne badanie endoskopowe. Wykazało ono dobrą skuteczność oczyszczania kanałów przepływowych, potwierdzając zmiany stanu technicznego profili łopatkowych i ich konsekwencje w postaci zarejestrowanych deformacji (rozwarstwienia) charakterystyki energetycznej części przepływowej silnika.

\section{Bibliography/Literatura}

[1] Balicki W., Korczewski Z., Szczeciński S.: Obszary zastosowań i tendencje rozwojowe turbinowych silników spalinowych. Silniki Spalinowe nr 3(130)/2007, s. 3-15.

[2] Balicki W.: Wpływ warunków i zakresów pracy oraz cech termodynamiczno-przepływowych turbinowych silników odrzutowych na informację diagnostyczną. WAT, Warszawa 1997.

[3] Błachnio J., Bogdan M.: A non-destructive method to assess a degree of overheating of gas turbine blades. Journal of Polish CIMAC. Diagnosis, Reliability and Safety. Vol.2 No. 2. 2007.

[4] Cohen H., Rogers G.F.C., Saravanamuttor H.I.H.: Gas turbine theory. Longman Scientific \& Technical, New York 1987.

[5] Ferrie J.: The Rolls-Royce Spey marine gas turbine, Transactions IMarE, Vol 102, part 5, England 1990.

[6] Hardin J.R. and others.: A gas turbine condition - monitoring system. Naval Engineers Journal, November, USA 1995.

[7] Korczewski Z.: Metoda diagnozowania części przepływowej okrętowego turbinowego silnika spalinowego w eksploatacji. AMW, Gdynia 1992.

[8] Korczewski Z.: Identyfikacja procesów gazodynamicznych w zespole sprężarkowym okrętowego turbinowego silnika spalinowego dla potrzeb diagnostyki. Monografia. AMW, Gdynia 1999.

[9] Dokumentacja techniczna i eksploatacyjna okrętowych turbinowych silników spalinowych Zorya typu UGT, General Electric typu LM2500 i LM1600. 